\title{
Immediate release of a nitric oxide-like factor from bovine aortic endothelial cells by Escherichia coli lipopolysaccharide
}

\author{
(L-arginine $/ N^{G}$-monomethyl-L-arginine/superoxide dismutase/endothelium-derived relaxing factor/platelets)
}

\author{
Daniela Salvemini*, Richard Korbut, Erik Änggård, and John Vane \\ The William Harvey Research Institute, Saint Bartholomew's Hospital Medical College, Charterhouse Square, London EC1M 6BQ, United Kingdom \\ Contributed by John Vane, December 26, 1989
}

\begin{abstract}
Incubation of human washed platelets with bovine aortic endothelial cells (ECs) treated with indomethacin resulted in an inhibition of thrombin-induced platelet aggregation that was dependent on the number of ECs added. Preincubation of ECs with Escherichia coli lipopolysaccharide (LPS; 0.5-2.0 $\mu \mathrm{g} / \mathrm{ml}$ ) for $1 \mathrm{~min}$ significantly enhanced their inhibitory activity. This effect was potentiated by superoxide dismutase ( 60 units $/ \mathrm{ml}$ ) and reversed by oxyhemoglobin (5-10 $\mu \mathrm{M})$, indicating that the inhibition was due to the release of endothelium-derived relaxing factor (nitric oxide). When the ECs were pretreated with $N^{G}$-monomethyl-L-arginine (30-300 $\mu M)$ before LPS, the antiaggregatory activity was strongly reduced. The reduction of activity by $N^{\mathbf{G}}$-monomethylL-arginine was reversed by L-arginine $(100 \mu \mathrm{M})$ but not by D-arginine $(100 \mu \mathrm{M})$. Under similar conditions, LPS also enhanced the antiaggregatory activity of ECs grown on beads. The immediate enhancement by LPS of the release of endothelium-derived relaxing factor from endothelial cells may contribute to the rapid fall in blood pressure associated with endotoxin shock in vivo.
\end{abstract}

Mammals infected with Gram-negative bacteria develop shock, characterized by hypotension, vascular injury, disseminated intravascular coagulation, and organ dysfunction (1). Escherichia coli is the most frequent causative agent in septic shock (2), the symptoms of which are primarily due to lipopolysaccharide (LPS). After a 4-hr incubation, LPS stimulates the generation of prostacyclin $\left(\mathrm{PGI}_{2}\right)$ from endothelial cells (3-5), which may contribute to the vasodilation (through a cAMP-mediated relaxation of vascular smooth muscle) and decreased arterial blood pressure in shock $(6,7)$.

Endothelium-derived relaxing factor (EDRF), which is released from the vascular endothelium in response to a number of stimuli (most of which also release $\mathrm{PGI}_{2}$ ), has been identified as nitric oxide (NO) $(8,9)$. NO is a potent vasodilator (10) and inhibits platelet aggregation (11-13) and platelet adhesion $(14,15)$ by stimulation of guanylate cyclase $(16)$. It is as yet not known whether NO is released in septic shock, although intraperitoneal LPS in rats elevates the urinary nitrate levels measured $18 \mathrm{hr}$ later (17).

$\mathrm{NO}$ in endothelial cells (ECs) is formed from the terminal guanido nitrogen of L-arginine (18). Its release from the endothelium is reduced $(18,19)$ by $N^{\mathrm{G}}$-monomethylL-arginine (LMA), an inhibitor of arginine metabolism to nitrogen oxides (20). When injected intravenously into rabbits (19), rats (21), or guinea pigs (22), LMA induces a rise in blood pressure that is reversed by L-arginine. Infusion of LMA into the human forearm also reduces blood flow by $40 \%$ (23), an effect reversed by $\mathrm{L}$-arginine. These experiments strongly suggest that a basal release of NO contributes to the regulation of blood pressure.

The publication costs of this article were defrayed in part by page charge payment. This article must therefore be hereby marked "advertisement" in accordance with 18 U.S.C. $\$ 1734$ solely to indicate this fact.
Factors such as LPS or $\gamma$-interferon can induce the generation of NO in macrophages (24-26), a process that takes several hours to develop. We have now found that in cultured ECs, LPS stimulates the release of a NO-like factor within 1 $\min$.

\section{MATERIALS AND METHODS}

Materials. The composition of the Krebs' solution was 137 $\mathrm{mM} \mathrm{NaCl} / 2.7 \mathrm{mM} \mathrm{KCl} / 11.9 \mathrm{mM} \mathrm{NaHCO} / 0.3 \mathrm{mM}$ $\mathrm{NaH}_{2} \mathrm{PO}_{4} / 0.8 \mathrm{mM} \mathrm{MgSO} / 5.6 \mathrm{mM}$ glucose $/ 1 \mathrm{mM} \mathrm{CaCl}$. The cell culture medium consisted of Dulbecco's modified Eagle's medium with $10 \%$ (vol/vol) fetal calf serum, $0.2 \mathrm{mM}$ L-glutamine, penicillin (100 international units/ml), streptomycin (100 international units/ml), and gentamycin (0.1 $\mathrm{mg} / \mathrm{ml}$ ). Oxyhemoglobin (oxyHb) was prepared by reduction of bovine hemoglobin with sodium hydrosulfite as described (27). Human thrombin, hemoglobin (from bovine blood), superoxide dismutase (SOD; from bovine erythrocytes), bradykinin (BK), E. coli LPS (serotype 0127:B8), sodium hydrosulfite, L-arginine (free base), D-arginine (free base), sodium nitroprusside, and indomethacin were obtained from Sigma. 3-Isobutyl-1-methylxanthine was obtained from Aldrich. Kits for radioimmunoassay of cGMP and cAMP used cGMP or cAMP labeled at the $2^{\prime}$ position with succinyl$3-\left[{ }^{125} I\right]$ iodotyrosine methyl ester and were purchased from Amersham. Hepes buffer, penicillin, streptomycin, and gentamycin were obtained from Flow Laboratories. Fetal calf serum and Hanks' balanced salt solution were obtained from GIBCO. The bovine aortae were obtained from a local abattoir. The arginine analogue $N^{G}$-monomethyl-L-arginine citrate was obtained from Ultrafine Chemicals (Manchester, U.K.). $\mathrm{PGI}_{2}$ was a gift from Wellcome.

Preparation of Washed Platelets. Human washed platelets treated with indomethacin $(10 \mu \mathrm{M})$ were prepared as described (28).

Preparation of Cultured ECs. ECs were obtained from bovine aortae and grown as monolayer cultures in $\mathrm{T} 75$ tissue culture flasks. When confluent, the ECs were treated briefly (10-20 sec) with $0.05 \%$ trypsin $1 \mathrm{hr}$ before use and centrifuged to form a pellet at $1000 \mathrm{rpm}$ in a Biofuge $A$ rotor for $5 \mathrm{~min}$. The pellet containing the ECs was then resuspended in Hanks' balanced salt solution (without $\mathrm{Ca}^{2+}$ and $\mathrm{Mg}^{2+}$ ) containing $10 \mathrm{mM}$ Hepes (HHBSS) and $10 \mu \mathrm{M}$ indomethacin at $\mathrm{pH}$ 7.4. The final EC count was adjusted to $4.5 \times 10^{6}$ or 9 $\times 10^{6}$ cells per $\mathrm{ml}$. In another set of experiments, after treatment with trypsin, ECs were seeded onto Cytodex 3 microcarrier beads (Pharmacia). The beads were stirred for 3-7 days until the cells became confluent and were used as

Abbreviations: NO, nitric oxide; EDRF, endothelium-derived relaxing factor; SOD, superoxide dismutase; oxyHb, oxyhemoglobin; ECs, endothelial cells; LPS, lipopolysaccharide; LMA, $N^{\mathrm{G}}$-monomethyl-L-arginine; $P \mathrm{PG}_{2}$, prostaglandin $\mathrm{I}_{2}$ or prostacyclin; $\mathrm{BK}$, bradykinin.

*To whom reprint requests should be addressed. 
a stock of $10-15 \times 10^{6}$ cells per $\mathrm{ml}$. Indomethacin $(10 \mu \mathrm{M})$ was added to these cells.

Cell Viability. Cell viability was assessed by trypan blue exclusion. Incubation of ECs for $1 \mathrm{~min}$ with LPS from 0.05 to $40 \mu \mathrm{g} / \mathrm{ml}$ did not lead to significant cell death (cell viability $>95 \%$ ).

Measurement of Platelet Aggregation. A suspension of washed platelets $(500 \mu \mathrm{l})$ was incubated at $37^{\circ} \mathrm{C}$ for $2 \mathrm{~min}$ in a Payton Dual Channel (Rotronic, U.K.) aggregometer (29) with continuous stirring at $1000 \mathrm{rpm}$ and then stimulated with submaximal concentrations of thrombin (20-80 milliunits/ $\mathrm{ml}$ ). The decrease in optical density was recorded for $3 \mathrm{~min}$ after thrombin addition. ECs in a volume of 2.5-50 $\mu$ l were added to the platelet suspension and the incubation continued for a further $1 \mathrm{~min}$ before stimulation with a submaximal concentration of thrombin. Cell numbers added were in the range of $0.11-4 \times 10^{5}$. When required LPS, BK, SOD, oxyHb, or any combination was added to the platelet suspension immediately before the addition of the ECs. LMA was preincubated with the ECs for 60 min either alone or with L-arginine or D-arginine. Inhibition of platelet aggregation was expressed as percent of maximal aggregation.

Potential Removal of Thrombin by ECs. A suspension of ECs obtained after treatment with trypsin in Krebs' buffer was incubated for $2 \mathrm{~min}$ with thrombin and then centrifuged at $10,000 \mathrm{rpm}$ for $1 \mathrm{~min}$ in a Biofuge A rotor. Plateletaggregatory activity of the supernatant was compared with the aggregatory activity of thrombin at the same concentration that was added to the suspension of ECs.

Determination of the Stability of the Factor Released from ECs. ECs in $500 \mu \mathrm{l}\left(2.2 \times 10^{6}\right.$ cells $)$ or ECs on beads in $500 \mu \mathrm{l}$ $\left(7.5 \times 10^{6}\right.$ cells) diluted with $500 \mu$ l of HHBSS with or without treatment with LPS $(20 \mu \mathrm{g} / \mathrm{ml})$ or BK $(120 \mathrm{ng} / \mathrm{ml})$ were stirred for $1 \mathrm{~min}$ and filtered through a Millipore filter (pore size, 0.2 $\mu \mathrm{m})$. The filtrate $(200 \mu \mathrm{l})$ was added to the washed platelets $(300 \mu \mathrm{l})$. The EC supernatant remained in contact with the platelets for $1 \mathrm{~min}$, then thrombin was added, and platelet aggregation was monitored for a further $3 \mathrm{~min}$. The aggregatory responses were compared to those obtained when $200 \mu \mathrm{l}$ of Krebs' solution was added to the $300 \mu$ l of platelets. In some experiments, the filtrate obtained after LPS or BK stimulation of the ECs was transferred to an Eppendorf tube for $5 \mathrm{~min}$ before testing its antiaggregatory activity.

Measurement of Cyclic Nucleotides. The concentration of cAMP or cGMP in ECs or platelets was measured with an acetylated radioimmunoassay kit. A suspension of washed platelets $(500 \mu \mathrm{l})$ or a suspension of ECs not on beads $(0.65 \times$ $10^{5}$ cells) was diluted to $500 \mu \mathrm{l}$ with Krebs' buffer and preincubated in an aggregometer for $1 \mathrm{~min}$ with the phosphodiesterase inhibitor 3-isobutyl-1-methylxanthine (0.1 mM). LPS $(20 \mu \mathrm{g} / \mathrm{ml})$ or an equivalent volume of Krebs' buffer $(5 \mu \mathrm{l})$ was then added, and the incubation was continued for a further 1 min. Ice-cold $10 \%$ (wt/vol) trichloroacetic acid was then added $(500 \mu \mathrm{l})$, the samples were stored at $-20^{\circ} \mathrm{C}$, and the cyclic nucleotides were extracted as described (30). All determinations were performed in duplicate.

Statistics. Results are expressed as mean \pm SEM for $(n)$ experiments. The quantitative character of the variables was assessed by the use of Student's unpaired $t$ test and linear regression analysis. $P<0.05$ was taken as significant.

\section{RESULTS}

Inhibition of Thrombin-Induced Platelet Aggregation by Bovine Aortic ECs. Thrombin (20-80 milliunits/ml) produced a submaximal (70-80\% of maximum) and irreversible aggregation of washed platelets within $3 \mathrm{~min}$. Addition of ECs $\left(0.65-4 \times 10^{5}\right.$ cells) to washed platelets inhibited thrombininduced platelet aggregation depending on the number of ECs added (Table 1). Hence, ECs in the aggregometer release a factor that inhibits platelet aggregation. Stirring the cell suspensions may contribute to the release of this factor (31).

The inhibition was not due to platelet dilution, for addition of corresponding volumes of HHBSS to the platelet suspension did not affect platelet aggregation. Furthermore, the inhibition was not due to thrombin uptake by ECs, because supernatants from suspensions of ECs that had been incubated with thrombin produced the same degree of aggregation that was obtained with thrombin alone. The number of cells needed to achieve a $23 \pm 3 \%$ inhibition in the experiments ( $n$ $=32$ ) varied between 0.65 and $1.5 \times 10^{5}$.

The inhibitory activity of $2.5 \times 10^{5}$ ECs was significantly increased by SOD ( 60 units/ml) and the inhibitory activity of $4 \times 10^{5}$ ECs was significantly attenuated by oxyHb $(10 \mu \mathrm{M})$ (Table 1). A 60-min preincubation of $4 \times 10^{5}$ ECs with LMA $(100 \mu \mathrm{M})$ reduced their ability to inhibit thrombin-stimulated platelet aggregation. L-Arginine $(100 \mu \mathrm{M})$ but not D-arginine $(100 \mu \mathrm{M})$ added with the LMA counteracted the effect of LMA $(100 \mu \mathrm{M})$ (Table 1). SOD (60 units/ml), oxyHb $(10 \mu \mathrm{M})$, or LMA $(300 \mu \mathrm{M})$ had no effect individually on thrombininduced platelet aggregation at the concentrations used.

$E$. coli LPS Enhances the Platelet-Inhibitory Activity of ECs. Preincubation of different numbers of ECs $\left(0.67-1.5 \times 10^{5}\right.$ cells) with LPS $(0.05-20 \mu \mathrm{g} / \mathrm{ml})$ for 1 min enhanced the antiaggregatory activity of the ECs. The minimum concentration of LPS required to induce a significant potentiation was $0.5 \mu \mathrm{g} / \mathrm{ml}$ (from $24 \pm 6 \%$ to $48 \pm 3 \% ; n=6 ; P<0.005$ )

Table 1. Inhibition of platelet aggregation by indomethacin-treated bovine aortic ECs

\begin{tabular}{ccccc}
\hline ECs, no. $\times 10^{-5}$ & Treatment & \% inhibition of platelet aggregation & $n$ & Significance $(P)$ \\
\hline 0 & None & $0^{*}$ & & \\
0.65 & None & $10 \pm 3$ & 9 & $<0.001^{*}$ \\
0.9 & None & $18 \pm 2$ & 6 & $<0.0005^{*}$ \\
1.3 & None & $37 \pm 3$ & 11 & $<0.0005^{*}$ \\
2.5 & None & $69 \pm 5^{\dagger}$ & 5 & $<0.0005^{*}$ \\
2.5 & SOD & 100 & 5 & $<0.005^{\dagger}$ \\
4.0 & None & $98 \pm 2^{\ddagger}$ & 5 & $<0.0005^{*}$ \\
4.0 & oxyHb & $23 \pm 5$ & 5 & $<0.0005^{\ddagger}$ \\
4.0 & LMA & $50 \pm 5^{\S}$ & 5 & $<0.0005^{\ddagger}$ \\
4.0 & LMA/L-arginine & $93 \pm 6$ & 5 & $<0.0005^{\S}$ \\
4.0 & LMA/D-arginine & $55 \pm 6$ & 5 & $<0.25^{\S}$ \\
\hline
\end{tabular}

Bovine aortic ECs reduced platelet aggregation stimulated by thrombin (20-80 milliunits $/ \mathrm{ml})$ according to cell number. Effects of $2.5 \times 10^{5} \mathrm{ECs}$ were potentiated by SOD $(60$ units $/ \mathrm{ml})$ and effects of $4 \times 10^{5} \mathrm{ECs}$ were reversed by oxy Hb $(10 \mu \mathrm{M})$ and prevented by LMA $(100 \mu \mathrm{M})$. When the cells were preincubated with LMA $(100 \mu \mathrm{M})$ for $60 \mathrm{~min}$, L-arginine $(100 \mu \mathrm{M})$ but not D-arginine $(100 \mu \mathrm{M})$ counteracted the effect of LMA. The results are expressed as percent inhibition of platelet aggregation (mean \pm SEM); $n$ represents the number of experiments. Footnote symbols indicate the results being compared. 
and that required for maximal activation was $10 \mu \mathrm{g} / \mathrm{ml}$ (from $24 \pm 6 \%$ to $90 \pm 4 \% ; n=6 ; P<0.0005$ ) (Table 2).

LPS alone applied for $1 \mathrm{~min}$ at the highest concentration tested $(40 \mu \mathrm{g} / \mathrm{ml})$ did not affect platelet aggregation, nor did it damage the ECs, as shown by light microscopy. In addition, the platelet-inhibitory effect of this dose of LPS was overcome when higher concentrations of thrombin (300 milliunits $/ \mathrm{ml}$ ) were used (results not shown). Thus the platelets could still respond to the aggregating agent. LPS did not change the $\mathrm{pH}$ of the EC medium. LPS at $20 \mu \mathrm{g} / \mathrm{ml}$ did not potentiate the antiaggregatory activity of sodium nitroprusside (results not shown).

In the presence of LPS $(20 \mu \mathrm{g} / \mathrm{ml})$ for $1 \mathrm{~min}$, the inhibitory activity of ECs was significantly potentiated so that fewer ECs were required to induce complete inhibition of platelet aggregation. The inhibitory activity of various concentrations of ECs in the absence or presence of LPS $(20 \mu \mathrm{g} / \mathrm{ml})$ is shown in Fig. 1. In the absence of LPS, the cell number required to inhibit thrombin-induced platelet aggregation by $50 \%\left(\mathrm{CN}_{50}\right)$, as calculated by linear regression analysis, was $1.96 \pm 0.35$ $\times 10^{5}$ cells $(r=0.9 ; Y=26.6 X \pm 3.2 ; n=36)$. In the presence of LPS, the $\mathrm{CN}_{50}$ was $0.37 \pm 0.19 \times 10^{5}$ cells $(r=0.9 ; Y=$ 68.9X $\pm 29.7 ; n=31$ ). Hence LPS induced at least a 5.3-fold potentiation of the inhibitory effects of ECs on platelet aggregation. Under these conditions, BK failed to enhance the antiaggregatory activity of ECs (results not shown).

Characterization of the Inhibitory Factor Released from LPS-Stimulated ECs. The inhibition of thrombin (20-80 milliunits $/ \mathrm{ml})$-stimulated platelet aggregation by ECs (0.67-1.5 $\left.\times 10^{5}\right)$ in the presence of LPS $(0.05-20 \mu \mathrm{g} / \mathrm{ml})$ was significantly potentiated by SOD (60 units/ml). oxyHb $(5 \mu \mathrm{M})$ prevented the SOD-induced potentiation (Fig. 1). These changes in platelet aggregation were confirmed by electron microscopy studies (not shown). In addition, the platelet inhibitory activity was filterable and decayed within $5 \mathrm{~min}$. When the supernatant from ECs was added directly to the platelet suspension, a significant inhibition of platelet aggregation was observed $(49 \pm 11 \%$ inhibition; $n=3 ; P<0.01)$. This inhibitory activity was enhanced when the ECs were stimulated with LPS $(20 \mu \mathrm{g} / \mathrm{ml})$ for $1 \mathrm{~min}$ (from $49 \pm 11 \%$ to $82 \pm 4 \%$ inhibition, respectively; $n=3 ; P<0.0005)$. When the filtrate of ECs stimulated by LPS was added 5 min after filtering, the increased antiaggregatory activity had disappeared $(n=3 ; P<0.2)$.

A 60 -min preincubation of the ECs $\left(0.67-1.5 \times 10^{5}\right)$ with LMA (30-300 $\mu \mathrm{M})$ reduced in a dose-dependent manner the ability of LPS $(20 \mu \mathrm{g} / \mathrm{ml})$ to enhance the antiaggregatory

Table 2. LPS enhances the inhibition by ECs of platelet aggregation induced by thrombin

\begin{tabular}{llcc}
\multirow{2}{*}{$\begin{array}{c}\text { LPS }, \\
\mu \mathrm{g} / \mathrm{ml}\end{array}$} & \multicolumn{3}{c}{ \% inhibition of platelet aggregation } \\
\cline { 2 - 4 } & Control & SOD & SOD + oxyHb \\
\hline 0 & $26 \pm 6$ & & \\
0.05 & $32 \pm 4$ & $99 \pm 1$ & $12 \pm 2$ \\
0.5 & $48 \pm 3^{*}$ & $95 \pm 4$ & $3 \pm 1$ \\
2.5 & $58 \pm 7^{*}$ & 100 & $8 \pm 4$ \\
5 & $69 \pm 6^{*}$ & $98 \pm 2$ & $17 \pm 6$ \\
10 & $89 \pm 4^{\dagger}$ & 100 & $12 \pm 6$ \\
20 & $97 \pm 1^{\dagger}$ & 100 & $8 \pm 3$
\end{tabular}

LPS enhanced the inhibition by ECs of platelet aggregation induced by thrombin (20-80 milliunits/ml). SOD at 60 units/ml further increased the effect, which was abolished by oxyHb at $5 \mu \mathrm{M}$. Preincubation of ECs with LPS $(0.05-20 \mu \mathrm{g} / \mathrm{ml})$ for $1 \mathrm{~min}$ resulted in a progressive increase in the inhibitory activity of the ECs, reaching maximum activity with LPS at $10 \mu \mathrm{g} / \mathrm{ml}$. SOD potentiated the inhibitory activity of LPS-treated cells and oxyHb prevented the SOD-induced potentiation. Results are expressed as percent inhibition of platelet aggregation. ${ }^{*} P<0.005$ and ${ }^{\dagger} P<0.0005$ when compared to the percent inhibitory activity of ECs in the absence of LPS.

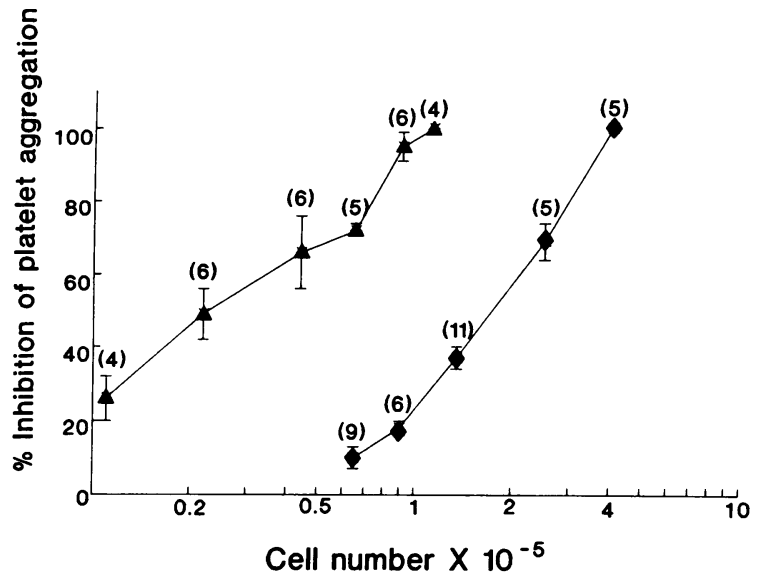

FIG. 1. Relative potency of ECs in inhibiting thrombin (20-80 milliunits/ml)-induced platelet aggregation in the presence $(\Delta)$ or absence $(\diamond)$ of LPS $(20 \mu \mathrm{g} / \mathrm{ml})$ after a 1-min incubation. In the presence of LPS, 10-20\% of the ECs were needed to induce a 50\% inhibition of platelet aggregation. Results (mean) are expressed as a percent inhibition of platelet aggregation. Vertical bars represent the SEM of $(n)$ experiments. Numbers in parentheses are $n$.

effect of the ECs. L-Arginine $(100 \mu \mathrm{M})$, but not D-arginine $(100 \mu \mathrm{M})$, incubated with LMA counteracted the effect of LMA at all concentrations tested (Fig. 2). These results show that the inhibitory factor released from ECs after stimulation with LPS has the pharmacological profile of NO and is identical to that released from ECs in the absence of LPS.

Platelet and EC Cyclic Nucleotides. Stimulation of ECs $(0.65$ $\times 10^{5}$ cells) with LPS $(20 \mu \mathrm{g} / \mathrm{ml})$ for $1 \mathrm{~min}$ led to a small but significant increase in the concentrations of cGMP in the ECs (from $365 \pm 45$ to $565 \pm 30$ fmol per $0.65 \times 10^{5}$ cells; $n=3$; $P<0.025$ ) with no changes in the levels of cAMP (from 615 \pm 15 to $615 \pm 15$ fmol per $0.65 \times 10^{5}$ cells; $n=3 ; P<0.2$ ). LPS $(20 \mu \mathrm{g} / \mathrm{ml})$ did not change the levels of cGMP in platelets (from $865 \pm 60$ to $975 \pm 105$ fmol per $0.5 \times 10^{8}$ platelets; $n=$ $3 ; P<0.2$ ) nor did it change the platelet level of cAMP (from $1635 \pm 115$ to $1185 \pm 170$ fmol per $0.5 \times 10^{8}$ platelets; $n=3$;

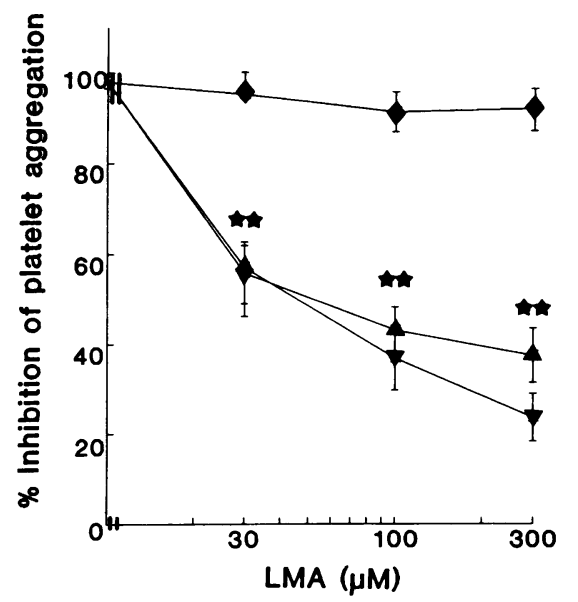

FIG. 2. Effect of LMA on the inhibition of thrombin (20-80 milliunits/ml)-induced platelet aggregation by ECs $\left(0.6-1.5 \times 10^{5}\right.$ cells) treated with LPS $(20 \mu \mathrm{g} / \mathrm{ml})$ for a 1-min incubation. Preincubation of ECs for 60 min with LMA (30-300 $\mu \mathrm{M})$ prevented, in a dose-dependent manner, their platelet-inhibitory activity induced by a 1-min stimulation with LPS $(\nabla)$. L-Arginine at $100 \mu \mathrm{M}(\diamond)$ but not D-arginine at $100 \mu \mathrm{M}(\Lambda)$ incubated with LMA counteracted the effect of LMA at all concentrations tested. Results (mean) are expressed as percent inhibition of platelet aggregation. Vertical bars represent the SEM of six experiments. $\star \star, P<0.0005$ when compared to the percent inhibitory activity of ECs in the absence of LMA. 


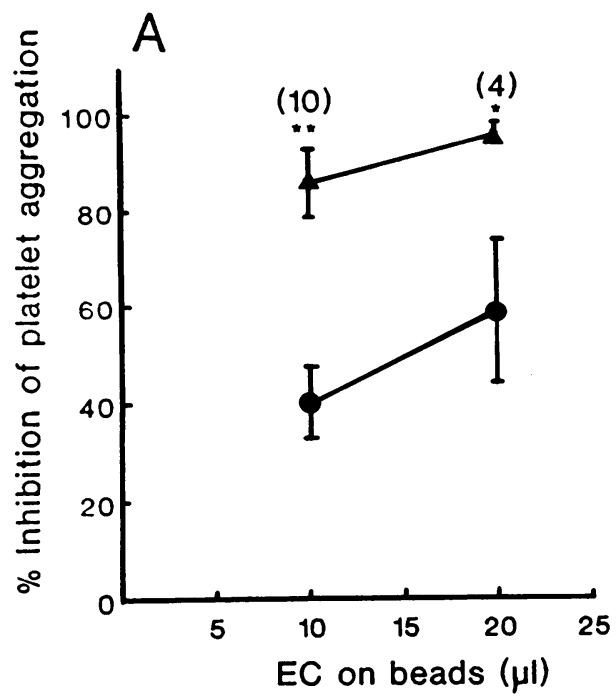

$P<0.2)$. No changes in platelet cAMP or cGMP were seen with LPS at concentrations up to $100 \mu \mathrm{g} / \mathrm{ml}$ (not shown).

$E$. coli LPS and BK Enhance the Platelet-Inhibitory Activity of ECs on Beads. The addition of $10 \mu \mathrm{l}(n=12)$ or $30 \mu \mathrm{l}(n=$ 3 ) of ECs on beads (corresponding to $1.5-3.5 \times 10^{5}$ cells) to a suspension of washed platelets inhibited thrombin-induced platelet aggregation $(30 \pm 8 \%$ and $95 \pm 3 \%$ inhibition, respectively). The platelet inhibitory activity of ECs on beads $(10 \mu \mathrm{l})$ was always further potentiated by SOD (60 units $/ \mathrm{ml})$ (from $15 \pm 2 \%$ to $97 \pm 3 \%$ inhibition; $n=3 ; P<0.0005$ ) and reversed when SOD was coincubated with oxyHb $(5 \mu \mathrm{M})$ (from $97 \pm 3 \%$ to $17 \pm 7 \%$ inhibition; $n=3 ; P<0.0005$ ). Preincubation of ECs on beads with LPS $(20 \mu \mathrm{g} / \mathrm{ml})$ for $1 \mathrm{~min}$ enhanced their antiaggregatory activity (Fig. 3A). Unlike suspensions of ECs when seeded on beads, the ECs released antiaggregatory activity after a 1-min stimulation with BK $(120 \mathrm{ng} / \mathrm{ml})$ (Fig. $3 B)$. As with ECs not on beads, the inhibitory factor released from ECs on beads after stimulation with LPS $(20 \mu \mathrm{g} / \mathrm{ml})$ or BK $(120 \mathrm{ng} / \mathrm{ml})$ was filterable and labile. When the supernatant from ECs was added directly to the platelet suspension a significant inhibition of platelet aggregation was observed when compared to control platelets $(25 \pm 7 \%$ inhibition; $n=4 ; P<0.01)$. This inhibitory activity was significantly enhanced when the ECs were stimulated with LPS (from $25 \pm 7 \%$ to $72 \pm 9 \%$ inhibition; $n$ $=4 ; P<0.005$ ) or with BK (from $25 \pm 7 \%$ to $68 \pm 11 \%$ inhibition; $n=4 ; P<0.01)$. When the supernatant of the ECs stimulated by LPS or BK was added to the platelet suspension $5 \mathrm{~min}$ after filtering, the antiaggregatory activity had disappeared $(n=4 ; P<0.2)$.

\section{DISCUSSION}

LPS stimulates the release of $\mathrm{PGI}_{2}$ from bovine and human ECs. This effect requires at least $4 \mathrm{hr}$ to develop and reaches a peak after about $10 \mathrm{hr}$. It is abolished by cycloheximide, indicating that protein synthesis is involved (32). Similarly, mouse peritoneal macrophages stimulated with LPS for $24 \mathrm{hr}$ generated nitrite and nitrate (24), the breakdown products of NO (33). This is due to the induction of at least one factor (34, 35). In the present study, we show that stimulation of indomethacin-treated bovine aortic ECs for only $1 \mathrm{~min}$ with LPS significantly enhanced the release of a NO-like factor, as measured by inhibition of platelet aggregation. Unlike the experiments quoted above, the induction step is clearly not necessary in the ECs that we used.

Several criteria are used to identify $\operatorname{EDRF}(N O)$-like substances. Like EDRF, the platelet inhibitory factor in our experiments was unstable, losing activity in $5 \mathrm{~min}$. NO survives longer when Krebs' buffer contains $\operatorname{SOD}(36,37)$, and in
(3)
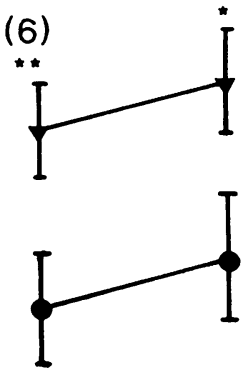
$(B)$ on the inhibition of thrombin (20 80 milliunits $/ \mathrm{ml}$ )-induced platelet aggregation by ECs on beads. The inhibition of thrombin-induced platelet aggregation by ECs $(\bullet)$ was markedly enhanced by a 1-min preincubation with LPS at $20 \mu \mathrm{g} / \mathrm{ml}(\Delta)$ or BK at 120 $\mathrm{ng} / \mathrm{ml}(\boldsymbol{\nabla})$. The results (mean) are expressed as percent inhibition of platelet aggregation. The vertical bars represent the SEM of $n$ experiments. $\star$, $P<0.05$ and $\star \star, P<0.025$ when compared to the percent inhibitory activity of ECs in the absence of LPS or BK.

our experiments SOD potentiated the effect of all concentrations of LPS tested. OxyHb oxidizes $\mathrm{NO}$ to $\mathrm{NO}_{3}^{-}$, destroying its biological activity $(38,39)$. In the presence of oxyHb, the inhibition of platelet aggregation observed with LPS and SOD was lost, demonstrating that the biological activity of this factor, like that of NO, is lost in the presence of oxyHb.

$\mathrm{NO}$ is synthesized in ECs from a nitrogen in the guanido group of L-arginine (18), and the L-arginine analogue LMA (20) inhibits NO released from ECs $(18,19)$. The activity of the inhibitory factor released from ECs after stimulation with LPS was abolished by preincubation of the cells with LMA, an effect that was overcome by L-arginine but not by Darginine. These results, therefore, strongly suggest that ECs grown in culture are stimulated by a 1-min incubation with LPS substantially to increase the release of a NO-like factor which in turn inhibits platelet aggregation. LPS stimulates the cGMP formation in rat fetal liver cells with no changes in cAMP (40). This is now best explained through the increased generation of NO induced in liver cells by LPS (41). Clearly in our experiments, LPS by itself did not increase the levels of the platelet cGMP or cAMP. However, LPS increased the levels of CGMP in ECs without altering the levels of CAMP. Such a finding is consistent with intracellular release of NO after EC stimulation, because there is an increase in cGMP when NO-generating cells are stimulated (40-43).

In our experiments, LPS did not stimulate in $1 \mathrm{~min}$ the release of $\mathrm{PGI}_{2}$ from ECs (unpublished observations), which is in accordance with the finding that increased $\mathrm{PGI}_{2}$ release from ECs after LPS stimulation develops over several hours (32).

LPS binds to platelets (44) and enhances their aggregatory response (45), but in our experiments LPS by itself did not alter the aggregatory effects of thrombin or change the platelet cyclic nucleotide levels.

Could the enhancement by LPS of the inhibition of platelet aggregation induced by ECs depend in any way on the use of platelets as the assay system? This is possible but unlikely, because LPS under the same experimental conditions and at the same concentration $(20 \mu \mathrm{g} / \mathrm{ml})$ did not enhance the inhibitory activity of another NO-generating cell, the mouse macrophage cell line J774 (46).

Pulsatile pressure, shear stress stirring, or thrombin causes the release of $\operatorname{EDRF}(31,47)$. Thus, when the ECs are added to the aggregometer, the release of EDRF is likely to be increased by the mechanical stirring. The lack of release of EDRF from BK-stimulated ECs that were not on beads may be due to the destruction of the BK receptor by the trypsin treatment an hour before the experiments. Indeed, trypsin removes certain receptors and there is a lag period before the receptors are reformed (48). The ECs on beads were used 
several days after trypsin treatment and the release of EDRF from these BK-stimulated cells suggests a recovery of the BK receptors. Other workers have noted that different experimental conditions influence the release of EDRF from BKstimulated ECs $(12,49,50)$. Since LPS was effective when using ECs on beads or not on beads, it is most likely that the increased release seen with LPS is due to activation of EDRF release by a mechanism different from that of BK.

The concentrations of LPS used here to stimulate NO release from ECs are similar to those used to produce pathological effects in vivo and in vitro. An intraperitoneal injection of LPS into mice elicits a marked increase in blood and urine levels of nitrite and nitrate after $18 \mathrm{hr}$ (24). The nitrogen oxide levels found in vivo after LPS injection into mice were thought to come from stimulated macrophages (24). Our results suggest that they may also be derived from stimulated ECs. This is further substantiated by the finding that ECs stimulated in culture for $18 \mathrm{hr}$ by $\gamma$-interferon and endotoxin release nitrate at levels comparable to those produced by activated macrophages (51).

Our results are further reinforced by one other study (52) on ECs that also showed an effect of LPS within 2 min, as measured by an oxygen burst. Nitrogen oxides are released from macrophages during the later phases of the action of LPS (24-26, 53). In contrast, our experiments show release of a NO-like factor within $1 \mathrm{~min}$. Since in vivo the blood pressure falls rapidly in response to endotoxin (1), it is attractive to speculate that NO may be involved in the early stages of shock. Thus $\mathrm{PGI}_{2}$ and NO may cooperate during the changes of vascular responsiveness seen in endotoxin shock.

We are indebted to Ms. E. Wood for culturing the ECs, to Dr. G. Lewis for electron microscopy, and to Dr. R. Botting for editorial assistance. The William Harvey Research Institute is supported by a grant from Glaxo Group Research Ltd.

1. Proctor, R. A., ed. (1986) Handbook of Endotoxin (Elsevier, Amsterdam), Vol. 4.

2. Cybulski, M. I., Chan, M. K. W. \& Movat, H. Z. (1988) Lab. Invest. 58, 365-378.

3. Nawroth, P. P., Stern, D. M., Kaplan, K. L. \& Nossel, H. L. (1984) Blood 64, 801-806.

4. Schorer, A. E., Kaplan, M. E., Rao, G. H. R. \& Moldow, C. F. (1986) Thromb. Haemostasis 56, 255-259.

5. Meyrick, B. O., Ryan, U. S. \& Brigham, K. L. (1986) Am. J. Pathol. 122, 140-151.

6. Harris, R. H. J., Zmudka, M., Maddox, Y., Ramwell, P. N. \& Fletscher, J. R. (1980) Advances in Prostaglandin Thromboxane Research, eds. Samuelsson, B., Ramwell, P. W. \& Paoletti, R. (Raven, New York) Vol. 7. pp. 843-849.

7. Bottoms, G. D., Templeton, C. B., Fessler, J. F., Johnson, M. A., Ruesel, O. F., Ewert, K. M. \& Adams, S. B. (1982) Am. J. Vet. Res. 43, 999-1002.

8. Palmer, R. M. J., Ferrige, A. G. \& Moncada, S. (1987) Nature (London) 327, 524-526.

9. Ignarro, L. J., Buga, G. M., Wood, K. S., Byrons, R. E. \& Chaudhuri, G. (1987) Proc. Natl. Acad. Sci. USA 84, 92659269.

10. Furchgott, R. F. \& Zawadzki, J. V. (1980) Nature (London) 288, 373-376.

11. Azuma, H., Ishikawa, M. \& Sekizaki, S. (1986) Br. J. Pharmacol. 88, 411-415.

12. Radomski, M. W., Palmer, R. M. J. \& Moncada, S. (1987) Br. J. Pharmacol. 92, 639-646.

13. Radomski, M. W., Palmer, R. M. J. \& Moncada, S. (1987) Br. J. Pharmacol. 92, 181-187.

14. Radomski, M. W., Palmer, R. M. J. \& Moncada, S. (1987) Lancet ii, 1057-1058.

15. Sneddon, J. M. \& Vane, J. R. (1988) Proc. Natl. Acad. Sci. USA 85, 2800-2804.

16. Rapoport, R. M., Draznin, M. B. \& Murad, F. (1983) Nature (London) 306, 174-176.
17. Leaf, C. D., Wishnok, J. S. \& Tannenbaum, S. R. (1989) Biochem. Biophys. Res. Commun. 163, 1032-1037.

18. Palmer, R. M. J., Ashton, D. S. \& Moncada, S. (1988) Nature (London) 333, 664-666.

19. Rees, D. D., Palmer, R. M. J. \& Moncada, S. (1989) Proc. Natl. Acad. Sci. USA 86, 3375-3378.

20. Hibbs, J. B., Taintor, R. R. \& Vavrin, Z. (1987) Science 235, 474-476.

21. Whittle, B. J. R., Lopez-Belmonte, J. \& Rees, D. D. (1989) Br. J. Pharmacol. 98, 646-652.

22. Aisaka, K., Gross, S. S., Griffith, O. W. \& Levi, R. (1989) Biochem. Biophys. Res. Commun. 160, 881-886.

23. Vallance, P., Collier, J. \& Moncada, S. (1989) Lancet ii, 9971000.

24. Stuehr, D. J. \& Marletta, M. A. (1985) Proc. Natl. Acad. Sci. USA 82, 7738-7742.

25. Iyengar, R., Stuehr, D. J. \& Marletta, A. M. (1987) Proc.Natl. Acad. Sci. USA 84, 6369-6373.

26. Stuehr, D. J. \& Marletta, M. A. (1987) Cancer Res. 47, 55905594.

27. Salvemini, D., de Nucci, G., Gryglewski, R. J. \& Vane, J. R. (1989) Proc. Natl. Acad. Sci. USA 86, 6328-6332.

28. Salvemini, D., de Nucci, G., Sneddon, J. M. \& Vane, J. R. (1989) Br. J. Pharmacol. 97, 1145-1150.

29. Born, G. V. R. \& Cross, M. J. (1963) J. Physiol. (London) 168, 178-195.

30. Martin, W., White, D. G. \& Henderson, A. H. (1988) Br. J. Pharmacol. 93, 229-239.

31. Stamler, J., Mendelsohn, M. E., Amarante, P., Smick, D., Andon, N., Davies, P. F., Cooke, J. P. \& Loscalzo, J. (1989) Circ. Res. 65, 789-795.

32. Delvos, U., Janseen, B. \& Muller-Berghaus, G. (1987) Blut 55, 101-108.

33. Sisler, H. H. (1956) in Comprehensive Inorganic Chemistry, eds. Sneed, M. C. \& Brasted, R. C. (Van Nostrand, Princeton), Vol. 5, pp. 60-67.

34. Hibbs, J. B., Taintor, R. R., Vavrin, Z. \& Rachlin, E. M. (1988) Biochem. Biophys. Res. Commun. 157, 87-94.

35. Stuehr, D. J., Kwon, N. S., Gross, S. S., Thieth, B. A., Levi, R. \& Nathan, C. F. (1989) Biochem. Biophys. Res. Commun. $161,420-426$.

36. Gryglewski, R. J., Palmer, R. M. J. \& Moncada, S. (1986) Nature (London) 320, 454-456.

37. Rubanyi, G. M. \& Vanhoutte, P. M. (1986) Am. J. Physiol. 250, H222- $\mathrm{H} 227$.

38. Haussmann, H. J. \& Werringloer, J. (1985) Naunyn-Schmiedebergs Arch. Pharmacol. 329, p. R21 (abstr.).

39. Ignarro, L. J. (1989) Semin. Hematol. 26, 63-76.

40. Graber, S. E. \& Clancey, M. A. (1985) Proc. Soc. Exp. Biol. Med. 180, 163-169.

41. Billiar, T. R., Curran, R. D., Stuehr, D. J., Ferrari, F. K. \& Simmons, R. L. (1989) Surgery 106, 364-372.

42. Schini, V., Schoeffter, P. \& Miller, R. C. (1989) Br. J. Pharmacol. 97, 853-865.

43. Schroder, H. \& Schor, K. (1989) Naunyn-Schmiedebergs Arch. Pharmacol. 340, 475-477.

44. Thorne, K. J. I., Oliver, R. C., Macintyre, D. E. \& Gordon, J. L. (1977) J. Cell. Sci. 28, 225-236.

45. Semeraro, N., Fumarola, D., Telesforo, P. \& Vermylen, J. (1976) Boll. Ist. Sieroter. Milan. 55, 577-586.

46. Salvemini, D., Korbut, R. \& Vane, J. R. (1990) in Nitric Oxide From L-Arginine: A Bioregulatory System, ed. Moncada, S. (Elsevier Biomed, Amsterdam), in press.

47. Rubanyi, G. M., Romero, J. C. \& Vanhoutte, P. M. (1986) Am. J. Physiol. 250, H1145-H1149.

48. Sung, C., Arleth, A. J., Shikano, K., Zabko-Potapovich, B. \& Berkowitz, B. A. (1988) Biochem. Pharmacol. 38, 696-699.

49. MacDonald, P. S., Read, M. A. \& Dusting, G. J. (1988) Thromb. Res. 49, 43-49.

50. Alheid, U., Frolich, J. C. \& Forstermann, U. (1987) Thromb. Res. 4, 561-570.

51. Kilbourn, R. \& Belloni, P. (1990). in Nitric Oxide From L-Arginine: A Bioregulatory System, ed. Moncada, S. (Elsevier Biomed, Amsterdam), in press.

52. Goligorsky, M. S. (1989) Am. J. Physiol. 257, C875-C881.

53. Stuehr, D. J., Gross, S. S., Sakuma, I., Levi, R. \& Nathan, C. F. (1989) J. Exp. Med. 169, 1011-1020. 